"Przegląd Prawa Konstytucyjnego"

- Nr 1 (13)/2013 ------

\title{
Recenzja
}

\section{Anna Rytel-Warzocha, Referendum ogólnokrajowe w państwach Europy Środkowo-Wschodniej, Wydawnictwo Sejmowe, Warszawa 2011, ss. 335}

Instytucja referendum ogólnokrajowego w państwach Europy Środkowo-Wschodniej, począwszy od 1989 r., była wykorzystywana wielokrotnie. Stosunkowo częste formalne odwoływanie się nowych elit rządzących do opinii obywateli w sprawach istotnych dla kraju traktowano jako sui generis receptę na ogólny kryzys demokracji reprezentatywnej i odziedziczony po latach komunizmu deficyt zaufania społeczeństwa do władzy. Prawnoustrojowa pozycja referendum ogólnokrajowego w młodych demokracjach Europy Centralnej nie była jednak dotąd przedmiotem osobnej monografii. Poszczególni badacze skupiali na nim uwagę wyłącznie w opracowaniach poświęconych pojedynczym państwom wskazanego regionu, analizując regulacje ustaw zasadniczych z tego zakresu lub wybrane przypadki stosowania tej instytucji ${ }^{1}$. Obszerna publikacja Referendum ogólnokrajowe w państwach Europy Środkowo-Wschodniej, będąca zmienioną i uaktualnioną wersją rozprawy doktorskiej A. Rytel-Warzochy, niewątpliwie wypełnia lukę w tej materii.

Jak podkreśliła we Wstępie Autorka, główną tezę pracy sprowadzić należy do twierdzenia, że referendum w postkomunistycznych krajach prezentowanego regionu stanowiło relewantne narzędzie procesu transformacji ustrojowej i tworzenia podstaw demokratycznego państwa prawnego. Wśród podjętych problemów badawczych przez A. Rytel-Warzochę znalazły się wskazanie roli przedmiotowej instytucji w poszczególnych państwach zakreślonego w tytule obszaru, analiza jej konstytucyjnej i ustawowej regulacji oraz omówienie ustrojowej prak-

1 Por. A. Frydrych, P. Raźny, Polska bibliografia wyborcza 1989-2010, Łódź 2010, opracowana w ramach badań Centrum Studiów Wyborczych Uniwersytetu Mikołaja Kopernika w Toruniu. 
tyki stosowania. Trzeba przyznać, że tak szeroko wytyczony zakres rozważań dał solidną podstawę pod dokonanie pogłębionej analizy prawnoporównawczej, a ta - już z samego założenia - musi być zajmująca. Zakres terytorialny monografii jest zresztą równie imponujący, co problemowy. Autorka uczyniła przedmiotem badań aż dziesięć państw Europy Środkowo-Wschodniej. I tak do prezentowanego regionu zaliczyła Polskę, Czechy, Słowację, Litwę, Łotwę, Estonię, Węgry, Słowenię oraz Rumunię i Bułgarię, a więc dziesięć państw, które przystąpiły do Unii Europejskiej odpowiednio w 2004 i 2007 r. O ile jednak w przypadku pierwszych siedmiu wymienionych państw nie ma wątpliwości, że powinny one zostać omówione w pracy o tak sformułowanym tytule, o tyle w odniesieniu do trzech ostatnich krajów położonych na Półwyspie Bałkańskim można wyrazić w tej kwestii pewne zastrzeżenia. Przykładowo, jeżeli Słowenię zaliczy się do kręgu państw Europy Środkowo-Wschodniej, to dlaczego z tego regionu wykluczać pozostałe państwa powstałe wskutek rozpadu byłej Jugosławii ${ }^{2}$, zwłaszcza że z obszarem tym skojarzono Rumunię i Bułgarię, co wskazuje na szerokie rozumienie zaproponowanego terminu. W tym miejscu można także postawić pytanie, dlaczego Białoruś i Ukraina nie zostały w pracy ujęte, skoro w tytule publikacji Autorka nie zaznaczyła, że zajmuje się wyłącznie wybranymi państwami regionu. Fragment Wstępu odnoszący się do wyboru państw, którym poświęcona została recenzowana pozycja tylko w niewielkim stopniu rozwiewa ewentualne wątpliwości w tej materii. Przytoczony fragment definicji hasła $E u$ ropa Środkowo-Wschodnia zaczerpnięty z internetowej Encyklopedii PWN zdaje się niewystarczający. W tym miejscu zabrakło jakiegokolwiek odwołania do literatury fachowej, chociażby sygnowanej przez lubelski Instytut Europy Środkowo-Wschodniej, która byłaby w argumentacji zaprezentowanego stanowiska bardzo pomocna. Co znamienne, J. Kłoczowski, dyrektor Instytutu i wybitny znawca tematyki, nierzadko podkreśla, że autorzy, podejmując problem Europy Środkowo-Wschodniej, każdorazowo muszą sami zająć stanowisko w sprawie wytyczenia jej granic, które w zależności od ujęcia czy wizji historycznej znacznie się od siebie różniąa ${ }^{3}$.

2 Nota bene na okładce książki umieszczono konturową mapę polityczną Europy, która uwzględnia stan granic sprzed rozpadu Jugosławii, ale z wykrojonym obszarem Słowenii i stosownym podpisem, podobnie jak podpisano pozostałe państwa omówione w publikacji.

3 Por. J. Kłoczowski, Europa Środkowowschodnia w przestrzeni europejskiej. Wyjaśnienie terminu, http://jazon.hist.uj.edu.pl (27.02.2012). 
Z uwagi na okoliczność, że monografia nie tylko skupia się na aktualnym stanie prawnym, ale w zasadniczej części dotyka zagadnień historycznych związanych $\mathrm{z}$ wprowadzeniem i normatywną ewolucją instytucji referendum, A. Rytel-Warzocha zastosowała w pracy metody dogmatycznoprawną i historycznoprawną, a dla wykazania tożsamości, podobieństw i różnic omawianej instytucji w poszczególnych porządkach prawnych wykorzystała metodę prawnoporównawczą. Użycie wspomnianych metod do konstrukcji wywodu zdeterminowało jego układ, który - co warto podkreślić - jest czytelny i logiczny. I tak, systematyka monografii obejmuje Wstęp, pięć rozdziałów, Wnioski końcowe, Bibliografie oraz Spis tabel. Rozdział pierwszy, zatytułowany Zagadnienia wprowadzające, składa się z dwóch części: pierwszej, poświęconej uwagom terminologicznym, i drugiej, traktującej o funkcjach referendum. Rozdział ten jest odpowiedzią na wieloznaczność i niedookreśloność elementarnych pojęć dotyczących tej instytucji. Zostały tu zdefiniowane kolejno terminy: „demokracja bezpośrednia”, „demokracja partycypacyjna”, „referendum”, „plebiscyt”, „recall” i „konsultacje ludowe”. Oznacza to, że Autorka ograniczyła swoje rozważania do niezbędnego minimum, pomijając takie instytucje - zwyczajowo prezentowane przy okazji omawiania demokracji bezpośredniej - jak: zgromadzenie ludowe (co zresztą związane jest $\mathrm{z}$ rezygnacją $\mathrm{z}$ omawiania korzeni demokracji bezpośredniej tkwiących $\mathrm{w}$ antyku), prawybory czy appelation of sentence. Zabieg ten $\mathrm{w}$ zestawieniu z odwołaniem do poglądów takich klasyków politologii, jak G. Sartori czy M. Duverger sprawia, że wywód jest klarowny dla czytelnika. Zaprezentowane kolejno typologie referendum według kryteriów: zasięgu terytorialnego, wymagalności przeprowadzenia głosowania w toku określonej procedury decyzyjnej, jego przedmiotu i etapu procedury stanowienia aktu, na którym się je przeprowadza, zapowiadają, jakie rodzaje przedmiotowej instytucji Autorka będzie omawiać w dalszych rozdziałach monografii. Wyczerpujące wyliczenie i scharakteryzowanie w końcu tej części publikacji funkcji referendum (m.in. funkcji bezpośredniego korzystania przez naród $\mathrm{z}$ atrybutu suwerenności, funkcji legitymizującej dla decyzji państwowych, funkcji artykulacyjnej, funkcji demokratyzacji życia publicznego, funkcji edukacyjnej czy funkcji kształtowania konsensusu społecznego i konfliktów społecznych), które - co trzeba zaznaczyć - nie jest regułą w opracowaniach z tego 
zakresu, uzupełnia poczynione uprzednio uwagi terminologiczne i zamyka rozważania wprowadzające.

Kolejne trzy rozdziały zawierają omówienie normatywnego kształtu referendum w poszczególnych krajach jednego spośród trzech wyodrębnionych przez Autorkę bloków państw. Każdy z nich podzielony został na cztery podrozdziały, które dotyczą odpowiednio: (I) historycznego rozwoju instytucji referendum w danym regionie (począwszy od dwudziestolecia międzywojennego, kiedy to $\mathrm{w}$ większości $\mathrm{z}$ omawianych państw instytucja ta została wprowadzona, poprzez okres socjalizmu charakteryzujący się stopniowym „przekonywaniem się" do niej przez elity rządzące, aż po okres transformacji ustrojowej, w którym referendum podlega coraz bardziej szczegółowej instytucjonalizacji), (II) konstytucyjnej regulacji referendum ogólnokrajowego (a zwłaszcza ustrojowego znaczenia tej instytucji i jej rodzajów), (III) ustawowego unormowania referendum (m.in. takich aspektów jak: prawa inicjatywy referendalnej i procedury jego wykonywania; kwestii zarządzenia referendum; sposobów głosowania, ustalenia wyników i mechanizmów ich weryfikacji; a także skutków przeprowadzenia różnych rodzajów referendum w związku z odmiennymi zasadami interpretacji ich wyników) i (IV) praktyki stosowania referendum po $1989 \mathrm{r}$.

W rozdziale drugim Autorka skupiła uwagę na państwach bałtyckich (Litwie, Łotwie i Estonii), rozdział trzeci poświęciła państwom Europy Środkowej (Czechom, Słowacji, Węgrom i Polsce), a w rozdziale czwartym opisała państwa bałkańskie (Słowenię, Bułgarię i Rumunię). Ich poszczególne części mają przejrzysty układ. Kolejne kwestie we wszystkich podrozdziałach lub punktach $\mathrm{z}$ tego zakresu prezentowane są „państwami”, omawianymi zawsze w tej samej sekwencji. Taki stan rzeczy pomaga z pewnością w odnajdywaniu wybranych treści w bardzo szczegółowej całości. Na podstawie przeglądu regulacji i faktów historycznych związanych $\mathrm{z}$ referendum można jednak postawić tezę, że wnikliwość Autorki sporadycznie cechowała pewna niekonsekwencja. Przykładowo w części rozdziału trzeciego - dotyczącej rozwoju historycznego przedmiotowej instytucji w okresie międzywojennym - wywód A. Rytel-Warzochy ma charakter dość luźno powiązanych ze sobą rozważań. O ile na początku Autorka słusznie odnosi się do instytucji referendum ogólnokrajowego przewidzianej w konstytucji Czechosłowacji z dnia 29 lutego 1920 r., o tyle 
omawiając Węgry i Polskę z racji braku analogicznych regulacji w tej materii wspomina - niejako wyłącznie dla utrzymania proporcji między poszczególnymi fragmentami tekstu - odpowiednio o plebiscycie w Sopron ${ }^{4}$ i o koncepcjach demokracji bezpośredniej w programach polskich stronnictw politycznych, ujawnionych w czasie prac nad uchwaleniem Konstytucji marcowej. Choć taka konstrukcja rozważań prima facie zbytnio nie razi, to dla bardziej wnikliwych czytelników zastanawiające może być, dlaczego Autorka wspomniała akurat o tym plebiscycie, skoro informacje o podobnych głosowaniach przeprowadzonych w analogicznych warunkach na Warmii, Mazurach i Powiślu czy Górnym Śląsku całkowicie przemilczała. Podobne wrażenie w kwestii wybiórczej prezentacji omawianych zagadnień można zresztą odnieść przy okazji lektury rozważań poświęconych ustawowym regulacjom referendum. W tych podrozdziałach szczególnie widoczny jest wpływ kształtu materii badawczej na treść zaprezentowanych rozważań. Wrażenie to w tym przypadku jest jednak mylne, ponieważ zachwiane proporcje objętościowe między częściami poświęconymi poszczególnym państwom wynikają z różnic w szczegółowości aktów normujących kwestie przygotowania i przeprowadzenia głosowania referendalnego. Za słusznością tej tezy niech przemówi okoliczność, że ustawa $\mathrm{z}$ tego zakresu na Węgrzech obejmuje jedynie dwadzieścia trzy artykuły, w Słowenii sześćdziesiąt jeden artykułów, a Polsce aż dziewięćdziesiąt osiem.

Rozdział piąty poświęcony został analizie prawnoporównawczej referendum ogólnokrajowego w prezentowanym regionie. Ta część monografii jest najbardziej rozbudowanym fragmentem pracy, liczącym ponad sześćdziesiąt stron. Jego struktura obejmuje aż siedem podrozdziałów, zatytułowanych odpowiednio: (I) Znaczenie ustrojowe referendum ogólnokrajowego w pań-

4 Plebiscyt ten był konsekwencją niekorzystnego dla Węgrów traktatu z Trianon, zgodnie z którym teren Burgenlandu przypadł Austrii. Do jego objęcia przez austriacką administrację jednak nie doszło. Na spornym terenie wybuchło zbrojne powstanie, w wyniku którego w październiku 1921 r. niepodległość proklamował nieuznany na arenie międzynarodowej Palatynat Litawski. Po mediacji Włoch ostatecznie niemal cały Burgenland przypadł Austrii. Jedynym ustępstwem na rzecz Węgrów było przeprowadzenie plebiscytu w największym ośrodku regio$\mathrm{nu}$, Sopronie, i jego okolicach. Por. K. Soós, Burgenland az európai politikában [Burgenland in European politics], Budapest 1971, s. 150-151, za: L. Gulyás, Beneš: Statesman or charlatan? The plans and the reality 1908-1948, Toronto-Buffalo 2007, s. 178-179. 
stwach Europy Środkowo-Wschodniej, (II) Miejsce regulacji referendum ogólnokrajowego, (III) Rodzaje referendum ogólnokrajowego w państwach Europy Środkowo-Wschodniej, (IV) Zarządzanie referendum ogólnokrajowego, (V) Kwestie proceduralne zwiazane $z$ przygotowaniem i przeprowadzeniem głosowania, (VI) Kwestie zwiazane z rezultatem głosowania, (VII) Kontrola nad referendum krajowym. Podrozdziały te podzielone zostały dodatkowo na punkty i podpunkty, dzięki czemu treść jest łatwiejsza. Rozważania zawarte w tym rozdziale nie ograniczają się wyłącznie do sfery normatywnej, ale - co bardzo ważne - odnoszą się także do sfery socjologii prawa (odesłania do przeprowadzonych głosowań), psychologii prawa (refleksje nad przyczynami absencji referendalnej), politologii (zaprezentowana typologia referendów) i psefologii (podjęcie zagadnień związanych $\mathrm{z}$ alternatywnymi sposobami głosowania). $\mathrm{W}$ rozdziale tym zagadnienia prawne omawiane są zatem $\mathrm{z}$ uwzględnieniem społecznego kontekstu ich występowania przy wykorzystaniu teorii psychologicznych i ustaleń nauk politycznych oraz studiów nad wyborami. Tak szerokie odniesienie pozwala czytelnikowi uzyskać pewność, że ma do czynienia z rzetelną wieloaspektową analizą prawnoporównawczą.

Niewątpliwą zaletą tej części książki jest zdecydowanie częstsze zajmowanie stanowiska przez Autorkę przy okazji omawianych kwestii, niż miało to miejsce we wcześniejszych rozdziałach. Przykładowo A. Rytel-Warzocha słusznie skrytykowała brak ustawowej regulacji referendum w Republice Czeskiej i organizowanie go na podstawie aktów prawnych wydawanych ad hoc, doszukując się w tym przypadku możliwości instrumentalnego wykorzystywania przedmiotowej instytucji. Innym postulatem, któremu nie można odmówić racji, jest konieczność zagwarantowania relatywnej niezmienności ustaw normujących przeprowadzenie referendum. Zdaniem Autorki analogicznie jak w polskim prawie wyborczym istotne zmiany nie powinny być wprowadzane na sześć miesięcy przed dokonaniem pierwszej czynności przewidzianej w kalendarzu wyborczym, tak samo nowelizowanie prawa referendalnego $\mathrm{w}$ okresie bezpośrednio poprzedzającym organizację referendum należałoby uznać za niedopuszczalne.

Przeprowadzone badania - w tym zwłaszcza analiza prawnoporównawcza - pozwoliły A. Rytel-Warzosze na wyodrębnienie uwag de lege ferenda odnośnie do polskiej regulacji referendum ogólnokrajowego. Niestety Au- 
torka, podnosząc tę kwestię we Wnioskach końcowych, nie wskazała dobitnie rodzimego ustawodawcy jako jedynego adresata tych postulatów. Zaprezentowane wnioski składają się na model optymalnie zaprojektowanego referendum, tak więc ich realizacja mogłaby nastąpić w realiach ustrojowych wszystkich omawianych państw. Co za tym idzie, Autorka nie wypunktowała skrupulatnie zalet i mankamentów polskiej ustawy, uchylając się tym samym od sformułowania propozycji jej kompleksowej nowelizacji. Szkoda, że zabrakło odniesień do kwestii prowadzenia i finansowania kampanii referendalnej czy potrzeby uregulowania wszystkich form demokracji bezpośredniej w jednym akcie prawnym. Czytelnik nastawiony na lekturę rozbudowanej oferty rozwiązań z tego zakresu z pewnością odczuje pewien niedosyt z powodu ich braku. Wśród postulatów zgłoszonych przez A. Rytel-Warzochę znalazły się za to m.in. propozycje: (1) zniesienia wymogu minimalnej frekwencji w głosowaniu i uzależnienia skuteczności referendum od odsetka uprawnionych, którzy poparli daną propozycję, (2) zastąpienia obowiązującej w przypadku referendum w wersji wielowariantowej zasady polegającej na tym, że wygrywa opcja, na którą oddano najwięcej głosów, normą, że referendum jest rozstrzygające, jeśli jedną z opcji poprze co najmniej trzydzieści procent obywateli, (3) przyznania obywatelom prawa bezpośredniej inicjatywy referendalnej, obligującej właściwy organ władzy do zarządzenia referendum, (4) wykorzystania instytucji referendum jako instrumentu wzmacniającego prawo wykonania inicjatywy ustawodawczej w sytuacji odrzucenia lub istotnej zmiany obywatelskiego projektu przez parlament i (5) przyjęcia ustawy regulującej podstawy przeprowadzenia referendum o charakterze konsultacyjnym. Nie sposób odmówić uwagom tym relewancji i sensu. Część z nich była zresztą podnoszona w doktrynie od dawna. Recenzowana monografia na pewno przyczyni się do ich popularyzacji.

Reasumując: publikacja A. Rytel-Warzochy Referendum ogólnokrajowe w państwach Europy Środkowo-Wschodniej jest udanym i wartościowym studium na unikatowy - nie tylko w polskich warunkach - temat. Lekturę jej treści można polecić konstytucjonalistom, politologom, psefologom, a także wszystkim zainteresowanym normatywną i praktyczną realizacją idei demokracji bezpośredniej. Ewentualne zastrzeżenia co do tytułu monografii czy też podniesione wyżej drobne uwagi krytyczne nie wpływają negatywnie na jej 
ocenę. Rzetelność przeprowadzonych badań odzwierciedla nie tylko obszerna bibliografia aktów prawnych, orzecznictwa i literatury fachowej, ale także rozbudowane przypisy nierzadko przybierające postać dygresji, wyjaśnień czy też polemik. Pozostaje wyrazić nadzieję, że na polskim rynku wydawniczym równie interesująca publikacja pojawi się w odniesieniu do referendum lokalnego.

Paweł Raźny (Uniwersytet Mikołaja Kopernika w Toruniu) 